\title{
Replication kinetics of duck enteritis virus UL16 gene in vitro
}

\author{
Qin He ${ }^{1,3}$, Anchun Cheng ${ }^{1,2,3^{*}}$, Mingshu Wang ${ }^{1,2,3^{*}}$, Jun Xiang ${ }^{1,3}$, Dekang Zhu ${ }^{2,3}$, Yi Zhou ${ }^{3}$, Renyong Jia ${ }^{1,2,3}$, \\ Shun Chen ${ }^{1,2,3}$, Zhengli Chen ${ }^{3}$ and Xiaoyue Chen ${ }^{2,3}$
}

\begin{abstract}
Background: The function and kinetics of some herpsvirus UL16 gene have been reported. But there was no any report of duck enteritis virus (DEV) UL16 gene.

Findings: The kinetics of DEV UL16 gene was examined in DEV CHv infected duck embryo fibroblasts (DEFs) by establishment of real-time quantitative reverse transcription polymerase chain reaction assay (qRT-PCR) and western-blotting. In this study, UL16 mRNA was transcript at a low level from 0-18 h post-infection (p.i), and peaked at $36 \mathrm{~h}$ p.i. It can't be detected in the presence of acyclovir (ACV). Besides, western-blotting analysis showed that UL16 gene expressed as an apparent 40-KDa in DEV infected cell lysate from $12 \mathrm{~h}$ p.i, and rose to peak level at $48 \mathrm{~h}$ p.i consistent with the qRT-PCR result.
\end{abstract}

Conclusions: These results provided the first evidence of the kinetics of DEV UL16 gene. DEV UL16 gene was a late gene and dependent on viral DNA synthesis.

\section{Findings}

Duck enteritis virus (DEV), caused duck viral enteritis (DVE), which was an acute, contagious and widespread disease in the family anatidae of the world, known as Duck plague virus (DPV), is a member of subfamily Alphaherpesvirinae of the family Herpesviridae, and has been assigned into Mardivirus genus [1,2]. DEV is composed of four structures, linear double strand DNA, icosahedral capsid, tegument and envelope. The DEV $\mathrm{CHv}$ strain complete genomic sequence and gene library has been constructed in our laboratory [3]. To date, a few of DEV genes of the kinetics has been identified and reported, such as US3 [4], UL31 [5], UL38 [6], UL45 [7], UL51 [8], and UTPase [9]. There was no report of DEV UL16 gene yet. In this study, real-time quantitative reverse transcription polymerase chain reaction assay (qRT-PCR) and western-blotting were used to determine the kinetics of DEV UL16 gene.

DEV CHv strain was propagated in DEFs. Growth medium consisted of MEM medium (Gibco-BRL)

\footnotetext{
* Correspondence: chenganchun@vip.163.com; mshwang@163.com ${ }^{1}$ Institute of Preventive Veterinary Medicine, Sichuan Agricultural University, Wenjiang, Chengdu city, Sichuan 611130, P.R.China

${ }^{2}$ Avian Disease Research Center, College of Veterinary Medicine of Sichuan Agricultural University, 46\# Xinkang Road, Ya'an, Sichuan 625014, P.R.China Full list of author information is available at the end of the article
}

supplemented with $10 \%$ calf serum and the maintenance medium supplemented with $2 \%$ calf serum. The monolayer DEFs was infected with the DEV CHv. Total cellular RNA was extracted at $0,0.5,1,2,4,6,8,12,18,24$, 36, 48, 60 and $72 \mathrm{~h}$ p.i, then the RNA was inversed transcribed to cDNA. The primers for qRT-PCR were UL16 (GeneBank Accession No. EU195095) F (5'-ATGCCG TGTTTATTGTC-3') and UL16 R (5'- GCGGGGTCG TTTCTACTG-3'), $\beta$-actin F ( $5^{\prime}$ - CCGGGCATCGCTG ACA- $\left.3^{\prime}\right)$ and $\beta$-actin $R\left(5^{\prime}\right.$ - GGATTCATCATACTCCT GCTTGCT-3'), Standard curves of PMD18-T/UL16 and PMD18-T/ $\beta$-actin (the recombinant plasmid was constructed in our laboratory) were established (Figure 1 and Figure 2). The transcription kinetics of the DEV UL16 gene in vitro infection was detected by the qRTPCR as described previous [7]. The qRT-PCR was performed in an $20 \mu \mathrm{l}$ reaction mixture containing cDNA $2 \mu \mathrm{l}$, SYBR Green II Mix $10 \mu \mathrm{l}, 1.0 \mu \mathrm{l}$ primers $(10 \mathrm{pmo1} / \mathrm{L})$ respectively, adding ultrapure water to $20 \mu$. The qRT-PCR consisted of an initial 5 min denaturation step at $95^{\circ} \mathrm{C}$, followed by 45 cycles of denaturation $\left(94^{\circ} \mathrm{C}, 30 \mathrm{~s}\right)$, annealing $\left(60^{\circ} \mathrm{C}, 30 \mathrm{~s}\right)$, and extension $\left(72^{\circ} \mathrm{C}, 30 \mathrm{~s}\right)$. Then the fluorescence and melt curve was measured. The relative amount of the UL16 mRNA expression was measured by the method of $2^{-\Delta \Delta C t}[10]$. As seen in
C Biomed Central

(c) 2012 He et al.; licensee BioMed Central Ltd. This is an Open Access article distributed under the terms of the Creative Commons Attribution License (http://creativecommons.org/licenses/by/2.0), which permits unrestricted use, distribution, and reproduction in any medium, provided the original work is properly cited. 


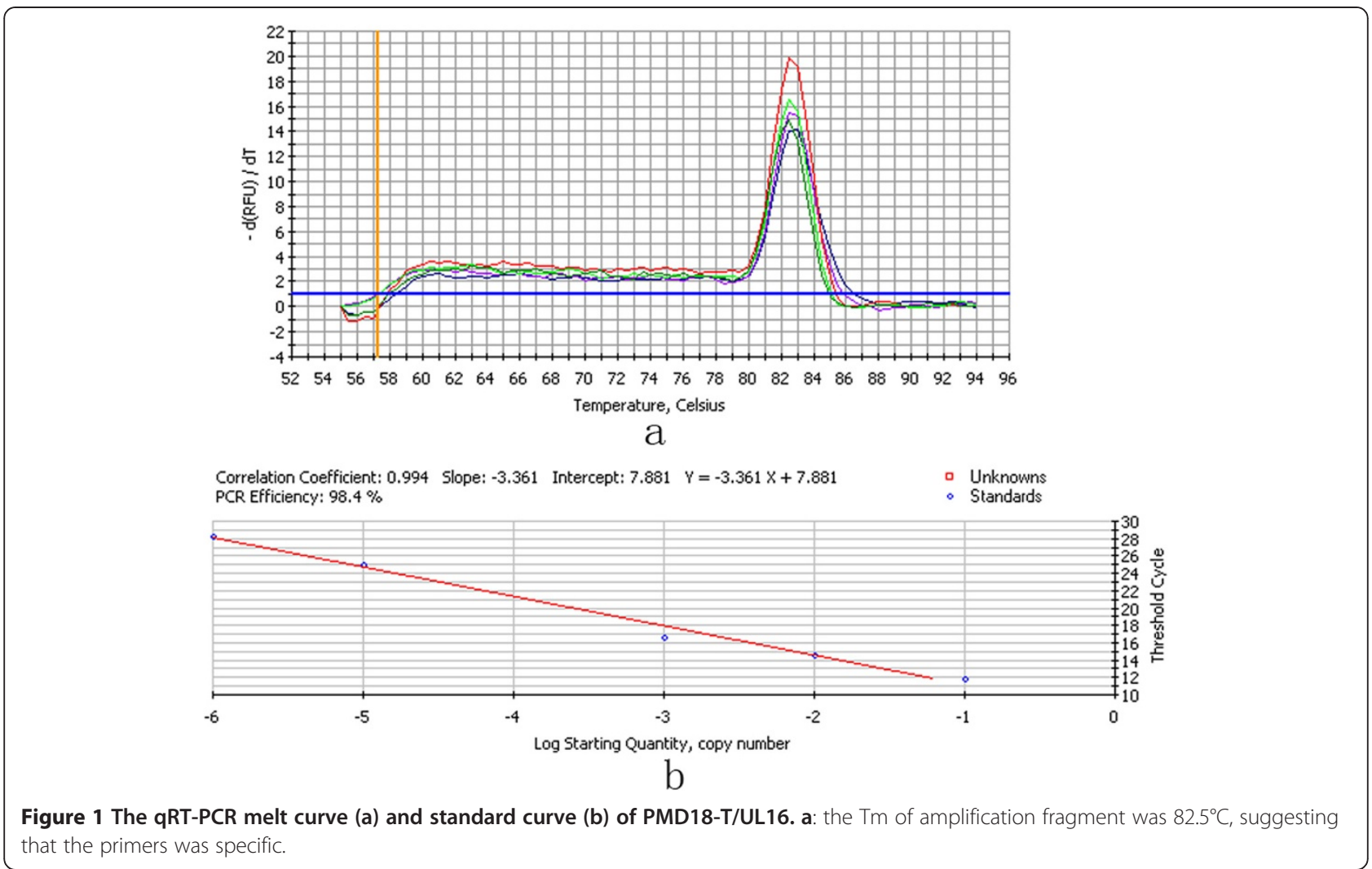

Figure 3, transcription of DEV UL16 mRNA was at low level from $0-18 \mathrm{~h}$, peaked at $36 \mathrm{~h}$, and then reduced after $48 \mathrm{~h}$ p.i.

To determine the UL16 protein synthesis was highly dependent on viral DNA synthesis, infected DEFs were maintained for $36 \mathrm{~h}$ after a $1-2 \mathrm{~h}$ adsorption in the presence or absence of ACV $(300 \mu \mathrm{g} / \mathrm{ml})$. The RNA was extracted and inversed transcribed to cDNA. The PCR was performed as above. The result showed that the UL16 couldn't be detected in the presence of ACV (Figure 4), indicating that the UL16 is a true late gene. ACV penetrated infected cells, converting to triphosphate form and then binding to viral deoxyribonucleic acid polymerase, then the viral DNA synthesis was inhibited [11]. As reported in the previous study, no detectable amount of the HSV-2 UL16 protein was produced in the presence of ACV [12]. The same result was obtained when the HSV-1 was in the presence of PAA (a potential inhibitor of viral DNA synthesis) [13]. Hence, we concluded that the DEV UL16 gene may be a true late gene and the UL16 protein synthesis was highly dependent on viral DNA synthesis.

To confirm the kinetics of DEV UL16 gene expression, DEFs were infected with DEV CHv strain. Cell lysate were prepared at $0,8,12,18,24,36,48,60 \mathrm{~h}$ p.i. The rabbit anti-UL16 polyclonal sera was obtained in the previous study and saved in our laboratory [14]. The
DEV UL16 protein was detected using the westernblotting assay. Showing in the Figure 5, an apparent $40 \mathrm{KDa}$ protein was detected at $12 \mathrm{~h}$ p.i. then increased over time and peaked at $48 \mathrm{~h}$ p.i. The qRT-PCR result showed that UL16 mRNA accumulated a maximum at $36 \mathrm{~h} \mathrm{p.i,} \mathrm{but} \mathrm{at} 48 \mathrm{~h}$ p.i in the western-blotting assay. The DNA was transcribed to mRNA, then the mRNA translated to protein. Hence, the highest level of the UL16 protein expression came after the peak of DEV UL16 mRNA. Previous researches had reported that UL16 or homologous-specific transcripts were detected only at late times of infection $[15,16]$, indicating that UL16 is regulated as $\gamma 2$ gene. UL16 genes are conserved in the whole herpes virus family and the function of UL16 gene may be involved in viral DNA packaging, virion assembly, budding, and egress $[12,13,17,18]$. The tegument protein of DEV UL51 was first detected at the late stage of infection. Genes can be sorted as immediate early gene (a), early gene $(\beta)$ and late gene $(\gamma)$ according to different transcription phase. Universally, structural proteins were encoded by late genes [19]. It could inferred that the DEV UL16 protein may be a structural protein. To confirm this hypothesis, more studies needed to be done.

In this work, we have firstly presented the kinetics of DEV UL16 gene. The productions of DEV UL16 gene accumulated at the late times of infection and couldn't 


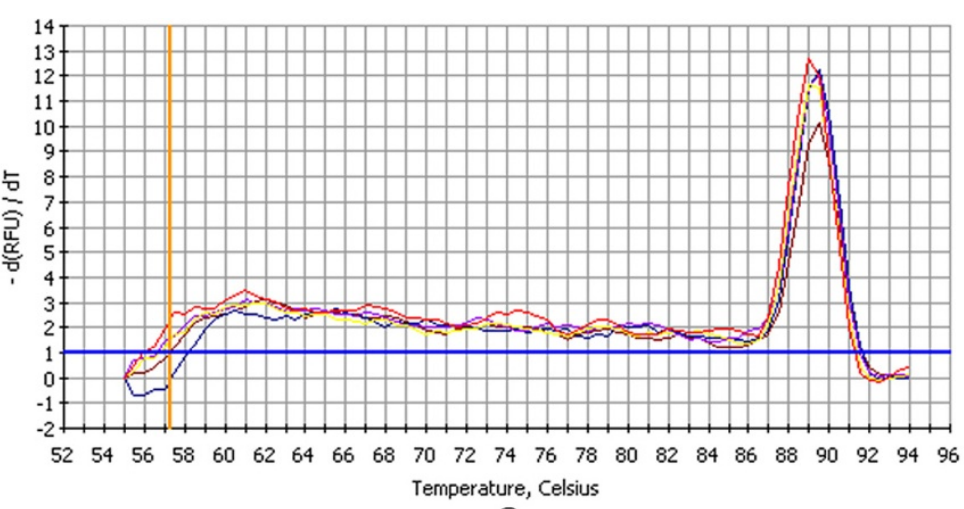

a

Correlation Coefficient: 0.997 Slope: -3.380 Intercept: $6.096 \quad \mathrm{Y}=-3.380 \mathrm{X}+6.096$ PCR Efficiency: $97.6 \%$

- Unknowns

- Standards

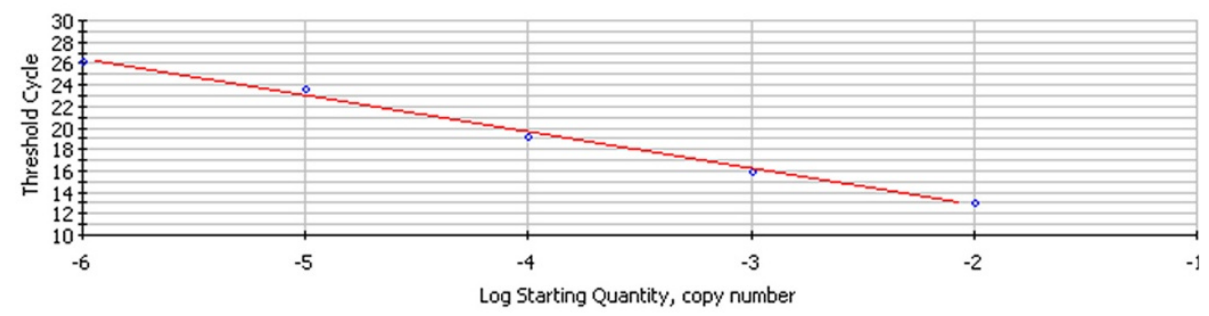

$b$

Figure 2 The qRT-PCR melt curve (a) and standard curve (b) of PMD18-T/ $\beta$-actin. a: the Tm of amplification fragment was $89.5^{\circ} \mathrm{C}$,

suggesting that the primers was specific.

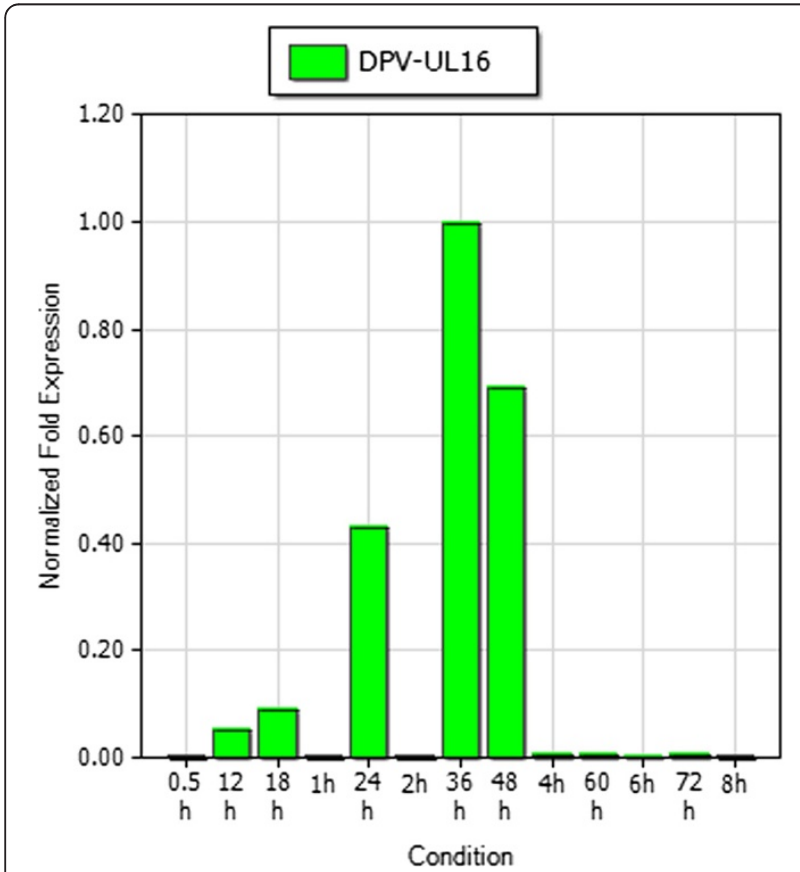

Figure 3 Kinetics of DEV UL16 gene transcription. The average relative content of the DEV UL16 gene transcripts was calculated at 0.5 , $1,2,4,6,8,12,18,24,36,48,60$ and $72 \mathrm{~h}$ p.i. using the $2^{-\Delta \Delta \mathrm{ct}}$ method.

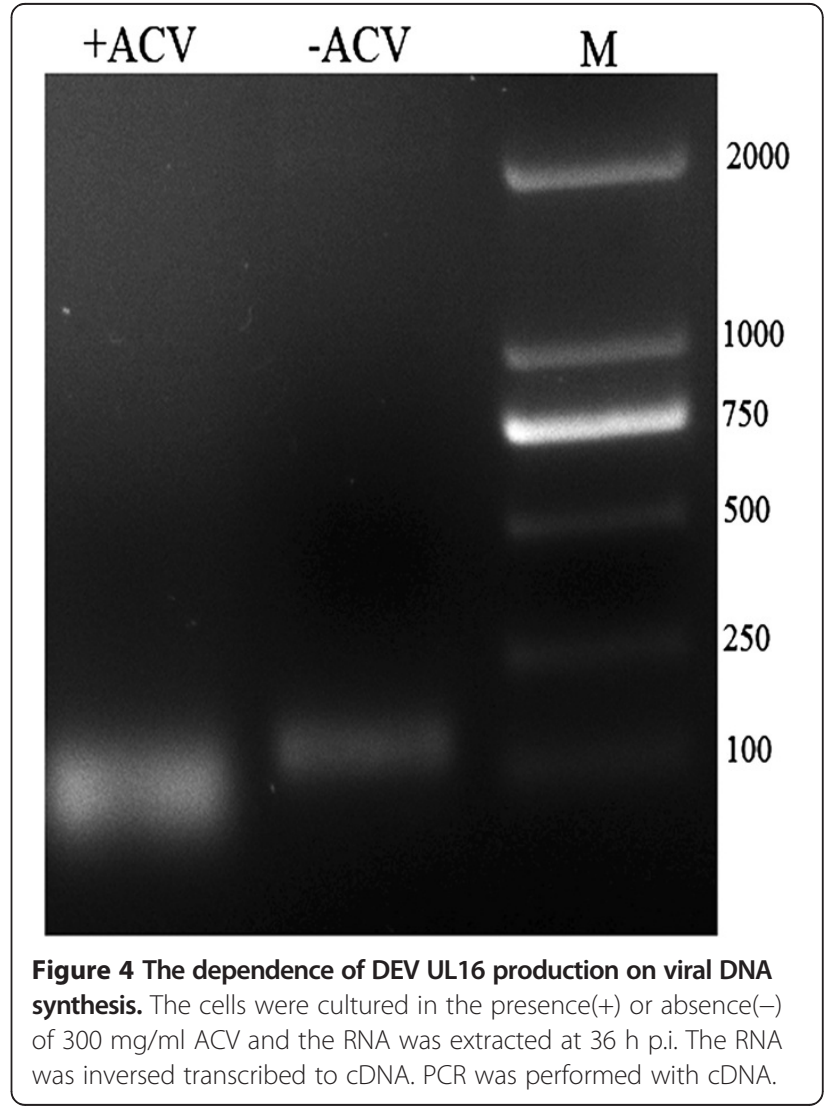




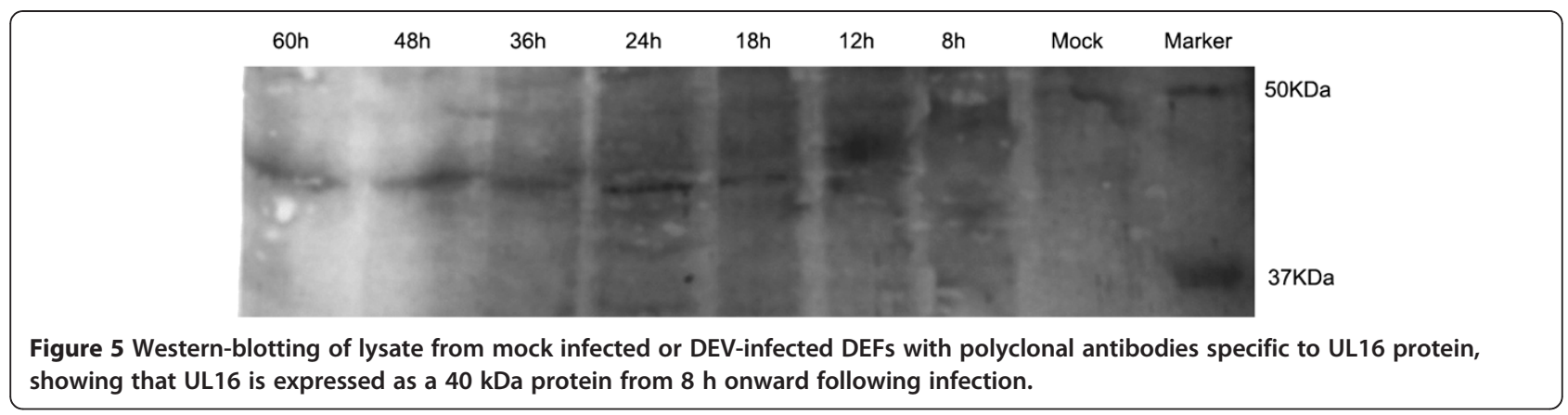

be detected in the presence of $\mathrm{ACV}$, suggesting that the UL16 gene belonged to $\gamma^{2}$ gene and might encode a structural protein which takes part in virion assembly, budding, and egress. The study is in accord with the earlier researches of HSV-1 UL16, HSV-2 UL16 and HCMV UL94 genes. All these results may provide some insights for further studies on the function of DEV UL16 gene.

\section{Competing interests}

The authors declare that they have no competing interests.

\section{Authors' contributions}

QH carried out most of the experiments and wrote the manuscript. ACC and MSW have critically revised the manuscript and the experimental design. DKZ, YZ, JX, RYJ, CZL and XYC helped in experiments and drafted the manuscript. All authors read and approved the final manuscript.

\section{Acknowledgement}

The research was supported by grants from China 973 program (2011CB111606), Changjiang Scholars and Innovative Research Team in University (PCSIRT0848) and China Agricultural Research System (CARS-43-8).

\section{Author details}

${ }^{1}$ Institute of Preventive Veterinary Medicine, Sichuan Agricultural University, Wenjiang, Chengdu city, Sichuan 611130, P.R.China. ${ }^{2}$ Avian Disease Research Center, College of Veterinary Medicine of Sichuan Agricultural University, 46\# Xinkang Road, Ya'an, Sichuan 625014, P.R.China. ${ }^{3}$ Key Laboratory of Animal Disease and Human Health of Sichuan Province, Sichuan Agricultural University, Wenjiang, Chengdu city, Sichuan 611130, P.R.China.

Received: 19 November 2011 Accepted: 23 October 2012 Published: 21 November 2012

\section{References}

1. Fadly AM, Glisson JR, McDougald LR, Nolan L, Swayne DE: Duck Virus Enteritis. Diseases of Poultry American: Wiley-BlackwellSaif YM; 2008:384-393.

2. King A, Lefkowita $E$, Adams MJ: Virus taxonomy: Ninth report of the International Committee on Taxonomy of Viruses. Elsevier 2011, 111-114.

3. Wu Y, Cheng AC, Wang MS, Yang Q, Zhu DK, Jia RY, Chen S, Zhou Y, Wang $X Y$, Chen XY: Complete genomic sequence of chinese virulent duck enteritis virus CHv stain. J Virol 2012, 10:5965-5965.

4. Xin HY, Cheng AC, Wang MS, Jia RY, Shen CJ, Chang H: Identification and Characterization of a Duck Enteritis Virus US3-Like Gene. Avian Dis 2009, 53:363-369

5. Xie W, Cheng AC, Wang MS, Chang H, Zhu DK, Luo QH: Expression and characterization of the UL31 protein from duck enteritis virus. Virol J 2009, 6:19.

6. Xiang J, Ma GP, Zhang SC, Cheng AC, Wang MS, Zhu DK, Jia RY, Luo QH, Chen ZL, Chen XY: Expression and intracellular localization of duck enteritis virus pUL38 protein. Virol J 2010, 7:162.

7. Shen AM, Ma GP, Cheng AC, Wang MS, Luo DD, Lu LT, Zhou T, Zhu DK, Luo QH, Jia RY, Chen ZL, Zhou Y, Chen XY: Transcription phase, protein characteristics of DEV UL45 and prokaryotic expression, antibody preparation of the UL45 des-transmembrane domain. Virol J 2010, 7:232.

8. Shen CJ, Guo YF, Cheng AC, Wang MS, Zhou Y, Lin D, Xin HY, Zhang N: Identification and characterization of the duck enteritis virus UL51 gene. Arch Virol 2009, 154:1061-1069.

9. Zhao LC, Cheng AC, Wang MS, Yuan GP, Jia RY, Zhou DC, Qi XF, Ge H, Sun $\mathrm{T}$ : Identification and characterization of duck enteritis virus dUTPase gene. Avian Dis 2008, 52:324-331.

10. Livak KJ, Schmittgen TD: Analysis of relative gene expression data using real-time quantitative PCR and the $2^{-\Delta \Delta \mathrm{Ct}}$ method. Methods 2001, 25:402-408.

11. Park NH, Langston AP, Mclean SL, Albert AM: Therapy of experimental herpes simplex encephalitis with acyclovir in mice. Antimicrob Agents Chemother 1979, 15:775-779.

12. Oshima S, Daikoku T, Shibata S, Yamada H, Goshima F, Nishiyama Y: Characterization of the UL 16 gene product of herpes simplex virus type 2. Arch Virol 1998, 143:863-880.

13. Nalwanga D, Rempel S, Roizman B, Baines JD: The UL16 gene product of herpes simplex virus 1 is a virion protein that colocalizes with intranuclear capsid proteins. Virology 1996, 226:236-242.

14. He Q, Yang Q, Cheng AC, Wang MS, Xiang J, Zhu DK, Jia RY, Luo QH, Chen ZL, Chen XY: Expression and characterization of Ul16 Gene from duck enteritis virus. Virol J 2011, 8:413.

15. Wing BA, Lee GC, Huang ES: The human cytomegalovirus UL94 open reading frame encodes a conserved herpes virus capsid/tegumentassociated virion protein that is expressed with true late kinetics. J Virol 1996, 70:3339-3345.

16. Guo H, Wang L, Peng L, Zhou ZH, Deng H: Open Reading Frame 33 of a Gammaherpesvirus Encodes a Tegument Protein Essential for Virion Morphogenesis and Egress. J Virol 2009, 83:10582-10595.

17. Baines JD, Roizman B: The open reading frames UL3, UL4, UL10, and UL16 are dispensable for the replication of herpes simplex virus 1 in cell culture. J Virol 1991, 65:938-944.

18. Meckes DG Jr, Wills JW: Dynamic interactions of the UL16 tegument protein with the capsid of herpes simplex virus. I Virol 2007, 81:13028-13036.

19. Weir JP: Regulation of herpes simplex virus gene expression. Gene 2001, 271:117-130.

doi:10.1186/1743-422X-9-281

Cite this article as: He et al:: Replication kinetics of duck enteritis virus UL16 gene in vitro. Virology Journal 2012 9:281. 